\title{
Upright plant architecture traits and their relationship with grain yield in the selection of Mesoamerican common bean lines cultivated at low altitude
}

\author{
N.D. Ribeiro, G.R. Kläsener, I.P. Somavilla and G.G. dos Santos \\ Departamento de Fitotecnia, Universidade Federal de Santa Maria, Santa \\ Maria, RS, Brasil \\ Corresponding author: N.D. Ribeiro \\ E-mail: nerineia@hotmail.com / nerineia.ribeiro@gmail.com
}

Genet. Mol. Res. 18 (2): gmr18323

Received April 12, 2019

Accepted June 24, 2019

Published June 26, 2019

DOI http://dx.doi.org/10.4238/gmr18323

\begin{abstract}
The development of common bean cultivars with upright plant architecture and high grain yield meets the needs of bean growers by facilitating culture management and mechanized harvest. The objectives of this study were to evaluate whether Mesoamerican common bean lines differ for upright plant architecture traits and grain yield, analyze correlations between these traits, and to select superior common bean lines based on a selection index. Four experiments were carried out in different years and growing seasons at low altitude ( $95 \mathrm{~m}$ above sea level) in southern Brazil. These experiments were composed of 17 carioca and black bean inbred lines, which are representative of the most widely produced and consumed common bean classes in Brazil. Upright plant architecture was assessed by 12 characters, and the resulting data were subjected to individual and joint analyses of variance, correlation, and selection index (rank sum). A significant effect for genotype and/or genotype $\mathrm{x}$ environment interaction was observed for all traits, except for the length of the first internode and hypocotyl diameter. Most plant architecture traits were correlated, indicating that it is possible to reduce the number of traits that need to be evaluated. Grain yield was negatively correlated with the lengths of
\end{abstract}


the fourth $(\mathrm{r}=-0.574)$ and fifth internodes $(\mathrm{r}=-0.641)$. General adaptation score, insertion of the first pod, and lengths of the fourth and fifth internodes were efficient to characterize upright plant architecture in the common bean. Indirect selection by the shortest length of the fourth and fifth internodes was efficient to increase grain yield. The genotypes LP 11-117, SM 0312, BRS Valente, and Guapo Brilhante were selected based on a rank sum index. These genotypes present upright plant architecture and high grain yield, which is a common bean ideotype suitable for cultivation at low altitude in southern Brazil.

Key words: Phaseolus vulgaris; Genetic variability; Pearson correlation; Rank sum index; Common bean ideotype

\section{INTRODUCTION}

Common bean (Phaseolus vulgaris) is grown in many countries and is a staple food widely consumed due to its high nutritional value and bioactive compounds that are beneficial to health (Chávez-Mendoza and Sánchez, 2017). Due to its great economic and social importance, the focus of most of common bean breeding programs has been increases in grain yield and the development of new cultivars with upright plant architecture.

Upright plant architecture in the common bean can be visually evaluated by the use of score scales, such as lodging (Mendes et al., 2011; Pereira et al., 2012; Jost et al., 2013; Soltani et al., 2016; Ribeiro et al., 2018a), plant growth habit (Silva et al., 2009), plant architecture (Acquaah et al., 1991; da Cunha et al., 2005; de Lima et al., 2012; Silva et al., 2013; Pires et al., 2014), and general adaptation score (Ribeiro et al., 2010; Ribeiro et al., 2018a). Although score scales are widely used in common bean breeding programs, it should be considered that such assessments depend on the evaluator's experience and usually present low repeatability.

Morphological traits have also been used to characterize upright plant architecture in common bean such as insertion of the first pod, plant height, length and number of internodes, among other traits described by Acquaah et al. (1991), Teixeira et al. (1999), Moura et al. (2013), and Ribeiro et al. (2018a). These traits have been assessed in samples from five to ten plants randomly harvested from an experimental plot (Schmit et al., 2016; Ribeiro et al., 2018a) or in all plants of a plot (Acquaah et al., 1991). This requires a lot of time and effort to obtain results, making the selection process inefficient. Therefore, it is important to examine the correlation and hereditability of the traits that confer upright plant architecture and grain yield in the common bean. This will allow us to identify the most effective traits for the selection of superior common bean genotypes.

Some breeders have suggested ideotype models for common bean, i.e., suitable morphological and phenological traits, among others, which together make up the ideal plant type for cultivation. Adams (1967) proposed a plant height between 50 and $55 \mathrm{~cm}$, indeterminate growth habit with short terminal vine (type II), and upper internodes longer and more numerous than basal ones as an ideotype model for common bean. Acquaah et al. (1991), in turn, made reference to the following ideotype model for the common bean: tall plant with a thick hypocotyl, and pods well distributed in the plant profile. Bertoldo et al. 
(2014) presented the following common bean ideotype: tall plants, long cycle, higher insertion of the first pod, greater number of pods per plant, and higher grain yield. Different traits can define the common bean ideotype. However, it is necessary to consider that the ideal common bean plant type will depend on the growing system, growing season and altitude of the region. Thus, is very important to assess and select the suitable ideotype model for the crop conditions.

No previous studies defining the common bean ideotype for cultivation at low altitude were found. Cultivation at low altitude ( $95 \mathrm{~m}$ above sea level) in southern Brazil is characterized by high air temperature and higher thermal sum, which contribute to a vigorous shoot growth of bean plants. The resulting fast vegetative growth makes the bean plants more susceptible to lodging, so it is important to select common bean cultivars with upright plant architecture. Considering the production data obtained in three growing seasons, Rio Grande do Sul (RS) state was the ninth on ranking of bean production in Brazil (Conab, 2019). However, in RS it is possible to produce beans only during two growing seasons, and approximately $80 \%$ of the bean production is obtained from family agriculture.

There is also no information in the literature about which visual or morphological traits characterize more precisely the upright plant architecture in the common bean. If selection for upright plant architecture is easily and quickly accomplished, using fewer traits to differentiate genotypes, this will result in more efficiency in the common bean breeding program. Thus, the objectives of this study were to evaluate whether Mesoamerican common bean lines differ for plant architecture traits and grain yield, analyze the correlations between these traits, and to select superior common bean lines for cultivation at low altitude, based on a selection index.

\section{MATERIAL AND METHODS}

Four experiments were carried out in the experimental area of the Plant Science Department, Federal University of Santa Maria (UFSM), in Santa Maria, Rio Grande do Sul, Brazil. The field area used for the study is located in the following geographic coordinates: latitude $29^{\circ} 42^{\prime} \mathrm{S}$, longitude $53^{\circ} 49^{\prime} \mathrm{W}$, and $95 \mathrm{~m}$ altitude, and the soil is classified as typical alitic Argisol, Hapludalf. The climate of the region is humid subtropical with warm summers and no definite dry season.

All experiments were conducted in a randomized blocks design with three replications. The experimental plots consisted of four $4 \mathrm{~m}$ rows, spaced at $0.5 \mathrm{~m}$. The useful area considered was $4 \mathrm{~m}^{2}$, since only the two central rows were used for the agronomic evaluations. Sowing was performed in October in the experiments of the rainy season (2016 and 2017) and in February for the dry season (2017 and 2018). These are the two recommended growing seasons for common bean in southern Brazil. In all experiments, was used $20 \%$ more seeds than necessary for each row, and at the growth stage of the first trifoliate leaf (V3), 15 plants per linear meter were thinned for a density equivalent to 250,000 plants/ha.

The treatments consisted of 17 common bean genotypes of the Mesoamerican gene pool, being 13 inbred lines and four cultivars (Table 1). The common bean lines evaluated integrated the experiment of Value of Cultivation and Use (VCU) in southern Brazil, during the biennium 2016 and 2018. The cultivars (control) used in this experiment are registered for cultivation in Rio Grande do Sul. The cultivars Pérola and Carioca have a prostrate plant 
architecture (indeterminate growth habit with long guides: type III), produce carioca-type grains, while the cultivars Guapo Brilhante and BRS Valente have an upright plant architecture (indeterminate growth habit with short guides: type II), and produce black grains. The genotypes evaluated are representative of the most grown types of beans in Brazil (carioca and black) and constitute the technological advances of common bean breeding programs in southern Brazil.

The management practices used in the four experiments were uniform, and the soil was conventionally prepared. The amount of calcareous and fertilizers used were calculated based on the interpretation of the soil analyses results. Control of weeds and insects was carried out as recommended for common bean culture in southern Brazil (Ctsbf, 2012). Fungicides were applied in the form of seeds treatment, and irrigation was made only when absolutely necessary for the establishment of the initial plant population, in compliance with VCU guidelines for beans (Brasil, 2006).

Table 1. Common bean genotypes evaluated, breeding program, commercial group, and growth habit.

\begin{tabular}{|c|c|c|c|}
\hline Genotype & Breeding Program & Commercial group & Growth habit \\
\hline 1. SM 0312 & FEPAGRO & Carioca & III \\
\hline 2. BRS MG Uai & EMBRAPA - AF & Carioca & III \\
\hline 3. Guapo Brilhante & EMBRAPA - CT & Black & II \\
\hline 4. TB $02-19$ & EMBRAPA - CT & Black & II \\
\hline 5. CHP 04-239-52 & EPAGRI & Black & II \\
\hline 6. LEC 01-16 & UEM & Carioca & III \\
\hline 7. LP 09-33 & IAPAR & Carioca & III \\
\hline 8. Carioca & IAC & Carioca & III \\
\hline 9. LP 11-117 & IAPAR & Black & II \\
\hline 10. CHP 01-182-48 & EPAGRI & Black & II \\
\hline 11. IAC Netuno & IAC & Black & II \\
\hline 12. BRS Valente & EMBRAPA - AF & Black & II \\
\hline 13. CNFC 15097 & EMBRAPA - AF & Carioca & III \\
\hline 14. GEN 45-2F-293P & IAC & Carioca & III \\
\hline 15. Pérola & EMBRAPA - AF & Carioca & III \\
\hline 16. LEC $02-16$ & UEM & Carioca & III \\
\hline 17. TB $03-11$ & EMBRAPA - CT & Black & II \\
\hline
\end{tabular}

Breeding Program: FEPAGRO: Agricultural Research State Foundation; EMBRAPA - AF: Brazilian Agricultural Research Corporation - Rice and Beans; EMBRAPA - CT: Brazilian Agricultural Research Corporation - Temperate Climate; EPAGRI: Agricultural Research and Rural Extension; UEM: State University of Maringá; IAPAR: Paraná Agronomic Institute; IAC: Campinas Agronomic Institute. Growth habit: II: indeterminate growth habit with short guides; III: indeterminate growth habit with long guides.

Upright plant architecture was assessed visually at the maturation stage (R9), in the useful area of the plots, using two scales: lodging and general adaptation score. For lodging, the scores ranged from 1 (upright plants) to 9 (prostrate plants, i.e., all plants fallen, touching the ground) (Ciat, 1987) were assigned. The general adaptation score was determined as described by Ribeiro et al. (2010), receiving score 1 (superior genotype) to the upright plants, with great number of pods per plant and no symptom of disease in the pods; and score 9 (inferior genotype) to all prostrate plants, with long internodes, few pods per plant and high severity of disease symptoms in pods.

Morphological traits were also analyzed to characterize upright plant architecture in the common bean. For this purpose, 10 plants were randomly harvested in the useful area at the R9 stage. First, insertion of the first pod, insertion of the last pod, and the plant height in 
the main branch were determined in $\mathrm{cm}$, using as reference the ground level. The lengths of the first, second, third, fourth, and fifth internodes were measured on the main branch of the plant in $\mathrm{cm}$, considering the distance from the cotyledonal node to the first internode (length of the first internode); the distance between the first internode and the second internode (length of the second internode): and so on, up to the distance between the fourth internode and the fifth internode (length of the fifth internode). The hypocotyl and epicotyl diameters were quantified with a digital caliper at a distance of $1 \mathrm{~cm}$ from the cotyledonal node.

The other plants grown on the useful area were harvested at the R9 stage. The grains were hand threshed and, when necessary, dried in an oven $\left(30^{\circ} \mathrm{C}\right)$ to $13 \%$ moisture. The grains obtained in the useful area and the 10 plants of each plot were weighed, and the grain yield was presented in $\mathrm{kg} / \mathrm{ha}$.

The data were subjected to individual and joint analyses of variance. Homogeneity of the residual variance was verified by the Hartley's maximum F test for all traits. The genotype $(\mathrm{G})$ and environment $(\mathrm{E})$ variation sources were considered as fixed effect, and the others (block, error, and $\mathrm{G} x \mathrm{E}$ interaction) were considered as random effect.

Pearson's linear correlation coefficients were estimated by using the phenotypic correlation matrix for all pairs of traits in which a significant difference to genotype and/or $\mathrm{G} \times \mathrm{E}$ interaction was observed, considering the mean data of the four experiments. The significance of the coefficients was assessed by the Student's $t$ test $(\mathrm{P}<0.05)$.

The rank sum index (Mulamba and Mock, 1978) was used to obtain heritability and genetic gain estimates and select the superior genotypes for upright plant architecture and grain yield. A $20 \%$ selection intensity was applied to select the four superior genotypes for the traits in which there was a significance difference for the genotype and/or $\mathrm{G} \times \mathrm{E}$ interaction. Statistical analyses were performed using the Genes software (Cruz, 2016).

\section{RESULTS AND DISCUSSION}

\section{Upright plant architecture and grain yield: experimental precision and genetic variability}

The variance of the experimental error was homogenous $(\mathrm{P}>0.05)$ for the four growing environments, which enabled the joint analysis of variance for all traits. The coefficient of experimental variation values were $\leq 22.85 \%$ (Table 2), which is a similar result to that obtained by Moura et al. (2013) and Ribeiro et al. (2018a, b) in the evaluation of traits that confer upright plant architecture and grain yield in Mesoamerican common bean genotypes. Therefore, all traits evaluated in our study presented high experimental precision when the coefficient of experimental variation was considered.

However, when the experimental precision was evaluated by the selective accuracy (SA), four classes were obtained: very high $(\mathrm{SA}>0.90)$ for insertion of the first pod, insertion of the last pod, plant height, epicotyl diameter, and grain yield; high $(0.70<\mathrm{SA}<$ 0.85 ) for lodging, general adaptation score, length of the second internode, length of the third internode, length of the fourth internode, and length of the fifth internode; moderate $(0.50<\mathrm{SA}<0.65)$ for the hypocotyl diameter; and low $(0.10<\mathrm{SA}<0.40)$ for the length of the first internode. These experimental precision classes were established by Resende and Duarte (2007) and can be applied to any trait and plant species. 
Table 2. Joint analysis of variance containing the degrees of freedom (DF), mean squares, mean, coefficient of experimental variation (CEV\%) and selective accuracy (SA) for the following traits: lodging (LOD), general adaptation score (GAS), insertion of the first pod (IFP, $\mathrm{cm}$ ), insertion of the last pod (ILP, $\mathrm{cm})$, plant height $(\mathrm{PH}, \mathrm{cm})$, length of the first internode $(\mathrm{L} 1 \mathrm{I}, \mathrm{cm})$, length of the second internode (L2I, $\mathrm{cm})$, length of the third internode (L3I, cm), length of the fourth internode (L4I, cm), length of the fifth internode (L5I, cm), hypocotyl diameter (HD, cm), epicotyl diameter (ED, cm), and grain yield (YLD, $\mathrm{kg} / \mathrm{ha}$ ) of 17 common bean genotypes assessed in four experiments carried out from 2016 to 2018.

\begin{tabular}{|c|c|c|c|c|c|c|}
\hline \multirow[b]{2}{*}{ Trait } & \multicolumn{3}{|c|}{ Mean square } & \multirow[t]{2}{*}{ Mean } & \multirow{2}{*}{$\begin{array}{l}\text { CVE } \\
(\%)^{1}\end{array}$} & \multirow[t]{2}{*}{ SA } \\
\hline & $\begin{array}{l}\text { Genotype }(G) \\
(D F=16)\end{array}$ & $\begin{array}{l}\text { Environment (E) } \\
(\mathrm{DF}=3)\end{array}$ & $\begin{array}{l}\text { G } \times \text { E interaction } \\
(\mathrm{DF}=48)\end{array}$ & & & \\
\hline LOD & $3.87^{*}$ & $26.80^{*}$ & $2.86^{*}$ & 5.24 & 22.27 & 0.805 \\
\hline GAS & $2.32^{*}$ & $21.61^{*}$ & $1.38^{*}$ & 5.61 & 16.47 & 0.795 \\
\hline IFP & $40.54^{*}$ & $980.65^{*}$ & $18.76^{*}$ & 15.65 & 14.40 & 0.935 \\
\hline ILP & $332.26^{*}$ & $12,223.86^{*}$ & $45.10^{\mathrm{ns}}$ & 42.57 & 15.00 & 0.937 \\
\hline $\mathrm{PH}$ & $814.87^{*}$ & $21,794.07^{*}$ & $141.04^{*}$ & 56.88 & 15.69 & 0.950 \\
\hline L1I & $0.42^{\text {ns }}$ & $21.40^{*}$ & $0.53^{\text {ns }}$ & 3.01 & 22.85 & 0.000 \\
\hline L2I & $1.39^{*}$ & $42.16^{*}$ & $0.67^{\mathrm{ns}}$ & 4.57 & 18.75 & 0.688 \\
\hline L3I & $1.65^{*}$ & $46.82^{*}$ & $0.86^{\mathrm{ns}}$ & 6.20 & 15.23 & 0.678 \\
\hline L4I & $4.03^{*}$ & $44.36^{*}$ & $2.05^{\mathrm{ns}}$ & 8.27 & 16.64 & 0.728 \\
\hline L5I & $9.01^{*}$ & $101.87^{*}$ & $4.32^{\mathrm{ns}}$ & 10.82 & 16.28 & 0.810 \\
\hline HD & $1.32^{\mathrm{ns}}$ & $52.23^{*}$ & $0.87^{\mathrm{ns}}$ & 5.76 & 15.82 & 0.607 \\
\hline ED & $1.30^{*}$ & $55.48^{*}$ & $0.45^{*}$ & 5.64 & 7.72 & 0.924 \\
\hline YLD & $633,763.14^{*}$ & $11,559,581.99^{*}$ & $415,363.89^{*}$ & 1389.42 & 21.59 & 0.926 \\
\hline
\end{tabular}

*Significant by the $\mathrm{F}$ test at 0.05 probability. ${ }^{\text {ns }}$ Not significant

For all upright plant architecture traits and grain yield a significant effect of the genotype and/or G x E interaction was observed, except for the length of the first internode and the hypocotyl diameter. However, previous studies reported significant different for the length of the first internode and the hypocotyl diameter in Mesoamerican common bean genotypes (Moura et al., 2013; Ribeiro et al., 2018a). These results reinforce the need to reassess which upright plant architecture traits are effective to evaluate genetic variability in the common bean germplasm. In our study, the common bean genotypes did not differ for the length of the first internode and the hypocotyl diameter, indicating that there was no genetic variability, which justifies not including these traits in the correlation and selection index analyses.

The following traits: lodging, general adaptation score, insertion of the first pod, insertion of the last pod, plant height, length of second, third, fourth and fifth internodes, and the epicotyl diameter enabled to differentiate the common bean genotypes with regard to upright plant architecture. Previous studies showed that Mesoamerican common bean genotypes differed for lodging (Mendes et al., 2011; Pereira et al., 2012); plant architecture score (da Cunha et al., 2005; de Lima et al., 2012); general adaptation score (Ribeiro et al., 2010); lodging and plant height (Soltani et al., 2016); lodging, general adaptation score, and insertion of the first pod (Jost et al., 2013); insertion of the first pod, plant height, length of the second, third, fourth and fifth internodes, and the epicotyl diameter (Moura et al., 2013); lodging, general adaptation score, insertion of the first pod, insertion of the last pod, plant height, length of the second and third internodes (Ribeiro et al., 2018a). Thus, all these traits can be used for the selection of common bean lines with upright plant architecture.

However, is not advisable to use only one trait to evaluate the plant architecture of common bean genotypes that have been selected by the breeding program, because such determination may present low repeatability in different growing environments. Also, is not 
advisable to evaluate several visual and morphological traits to analyze the plant architecture, because this may result in a too long and laborious selection process. Thus, is important that the number of traits studied allow to differentiate the genotypes easily, quickly and with high experimental precision. In the present study, all traits that presented a significant effect of the genotype and/or G x E interaction were also those that have a high or very high selective accuracy ( $\mathrm{SA} \geq 0.70$ ). Additionally, the correlation and heritability analyses among the traits that confer upright plant architecture and grain yield will be determinant in identifying of the most efficient traits to be used in common bean breeding programs.

\section{Correlations among the traits that confer upright plant architecture and grain yield}

Positive and high magnitude correlation estimates were obtained for the following traits: lodging and general adaptation score $(\mathrm{r}=0.810)$, lodging and insertion of the first pod $(r=0.792)$, insertion of the first pod and insertion of the last pod $(r=0.748)$, insertion of the first pod and plant height $(\mathrm{r}=0.603)$, and insertion of the last pod and plant height $(\mathrm{r}=$ 0.979) (Table 3). Similarly, high positive correlation was observed between insertion of the last pod and plant height in Mesoamerican common bean lines (Ribeiro et al., 2018a). However, no correlation was found between lodging and insertion of the first pod (Moura et al., 2013), and a positive and intermediate magnitude correlation was observed between lodging and general adaptation score (Jost et al., 2013) in Mesoamerican common bean lines. The differences found can be justified by the genetic diversity among the genotypes and by the great number of environments evaluated. In the present study, the correlation coefficient estimates were obtained from the mean data of four environments, involving different crop years and growing seasons, and for this reason they characterize more precisely the association between the trait pairs.

Table 3. Pearson linear correlation estimates between the following traits: lodging (LOD), general adaptation score (GAS), insertion of the first pod (IFP), insertion of the last pod (ILP), plant height (PH), length of the second internode (L2I), length of the third internode (L3I), length of the fourth internode (L4I), length of the fifth internode (L5I), epicotyl diameter (ED), and grain yield (YLD) of 17 common bean genotypes assessed in four experiments carried out from 2016 to 2018.

\begin{tabular}{|c|c|c|c|c|c|c|c|c|c|c|}
\hline & GAS & IFP & ILP & $\mathbf{P H}$ & L2I & L3I & L4I & L5I & ED & YLD \\
\hline LOD & $0.810^{*}$ & $0.792^{*}$ & 0.362 & 0.211 & -0.341 & -0.224 & -0.003 & 0.128 & $-0.661^{*}$ & 0.113 \\
\hline GAS & & 0.406 & -0.158 & -0.296 & 0.192 & 0.318 & 0.547 & $0.665^{*}$ & $-0.669^{*}$ & -0.338 \\
\hline IFP & & & $0.748^{*}$ & $0.603^{*}$ & $-0.622^{*}$ & $-0.584^{*}$ & -0.450 & -0.344 & -0.444 & 0.326 \\
\hline ILP & & & & $0.979^{*}$ & $-0.949^{*}$ & $-0.957^{*}$ & $-0.888^{*}$ & $-0.802^{*}$ & 0.201 & 0.357 \\
\hline $\mathrm{PH}$ & & & & & $-0.962^{*}$ & $-0.979^{*}$ & $-0.928^{*}$ & $-0.851^{*}$ & 0.375 & 0.319 \\
\hline L2I & & & & & & $0.988^{*}$ & $0.909^{*}$ & $0.823^{*}$ & -0.239 & -0.437 \\
\hline L3I & & & & & & & $0.958^{*}$ & $0.892^{*}$ & -0.302 & -0.469 \\
\hline L4I & & & & & & & & $0.982^{*}$ & -0.374 & $-0.574^{*}$ \\
\hline L5I & & & & & & & & & -0.390 & $-0.641^{*}$ \\
\hline ED & & & & & & & & & & -0.331 \\
\hline
\end{tabular}

* Significant by the $t$ test at 0.05 probability.

The results obtained in the correlation analysis allow us to infer that the increase of the lodging will result in higher general adaptation score and this repeats for the trait pairs, 
as follows: lodging - insertion of the first pod; insertion of the first pod - insertion of the last pod; insertion of the first pod - plant height; and insertion of the last pod - plant height. Highly correlated trait pairs show redundant information, and for this reason is not advisable to select for both traits simultaneously. In this case, selection of common bean lines with upright plant architecture may be performed using one or another trait. General adaptation score and insertion of the first pod, in turn, may be used jointly for the selection of common bean lines with upright plant architecture, because these traits were not correlated.

A high positive correlation $(\mathrm{r} \geq 0.823)$ was observed in all pairs of possible combinations between the lengths of the second, third, fourth and fifth internodes, confirming what was verified by Ribeiro et al. (2018a) with respect to the correlation between the length of the second and third internodes in Mesoamerican common bean. Of these, only the lengths of the fourth and fifth internodes were correlated with grain yield, $r=$ -0.574 and $r=-0.641$, respectively. These correlations were negative, so common bean plants with shorter lengths of the fourth and fifth internodes will present higher grain yield. This is explained by the fact that common bean plants with longer length of the fourth and fifth internodes tend to be decumbent. Common bean plants with numerous nodes and long internodes are prostrate, and lodge with branches and pods contacting the ground when there is excess precipitation close to harvest, a common condition in the rainy and dry growing seasons in southern Brazil. As common bean pods get in contact with wet soil, there is a loss in the quality of grains, resulting in decreased grain yield. For this reason, common bean lines with longer length of the fourth and fifth internodes usually have low grain yield when cultivated at low altitude.

The other upright plant architecture traits were not correlated with grain yield, confirming previous results observed by Moura et al. (2013), Silva et al. (2013), Maziero et al. (2015), and Ribeiro et al. (2018a) for Mesoamerican common bean. These results indicate independence of the genes controlling grain yield and plant architecture in the common bean, which is in accordance with what was previously observed by da Cunha et al. (2005). However, is important that the breeding program also assess and select common bean plants with upright plant architecture, because it meets bean growers' demand. This is because upright plants facilitate mechanical harvest, usually exhibit less disease incidence and higher grains quality, since the pods do not touch the ground (de Lima et al, 2012).

The following upright plant architecture traits showed negative and high magnitude correlation estimates: insertion of the first pod with the lengths of the second and third internodes; insertion of the last pod with the lengths of the second, third, fourth, and fifth internodes; plant height with the lengths of the second, third, fourth and fifth internodes; and epicotyl diameter with lodging and general adaptation score. These results confirm that the selection of common bean plants with upright architecture based in many visual and morphological traits are not efficient, because many of these traits are highly correlated.

In the present study was verified that general adaptation score and insertion of the first pod can be used to evaluate upright plant architecture in Mesoamerican common bean lines. These traits were not correlated (Table 3) and presented high selective accuracy (Table 2). The lowest lengths of the fourth and fifth internodes can be used for indirect selection of common bean lines with high grain yield (Table 3) and also showed high selective accuracy (Table 2). Therefore, general adaptation score, insertion of the first pod, and lengths of the fourth and fifth internodes traits were effective in characterizing the 
upright plant architecture in Mesoamerican common bean genotypes cultivated at low altitude. The evaluation of these traits is easy, quick, and have high experimental precision, and can be implemented in the routine of common bean breeding programs.

\section{Combined selection for upright plant architecture and grain yield}

The combined selection was carried out based on a rank sum index (Mulamba and Mock, 1978) in order to increase the following traits: insertion of the first pod, epicotyl diameter, length of the second internode, length of third internode, and grain yield. For the other traits, the selection aimed at the lowest values, i.e., to obtain negative genetic gain estimates. To this, weight 3 was assigned to grain yield (trait of great importance for the breeding program), weight 2 was attributed to the lengths of the fourth and fifth internodes (traits correlated with grain yield), and weight 1 was applied for the other traits evaluated.

High heritability $\left(\mathrm{h}^{2}: 63.20\right.$ to $\left.93.20 \%\right)$ for upright plant architecture traits and grain yield was obtained (Table 4). These values were similar to those reported earlier in Mesoamerican common bean experiments for lodging (Mendes et al., 2011; Jost et al., 2013; Soltani et al., 2016), insertion of the first pod (Bertoldo et al., 2010), plant height (Bertoldo et al., 2010; Carneiro et al., 2017), and grain yield (Mendes et al., 2011; Jost et al., 2013). When heritability is high, genetic variance is the main component of phenotypic variance, indicating progress in genetic breeding due to the great genetic variability observed for the traits evaluated.

Table 4. Mean of the original population $\left(X_{0}\right)$, mean of selected genotypes $\left(X_{S}\right)$, heritability $\left(h^{2} \%\right)$, genetic gain $(\mathrm{GG})$, and percentage of genetic gain $(\mathrm{GG} \%)$ with simultaneous selection by the rank sum index for the following traits: lodging (LOD), general adaptation score (GAS), insertion of the first pod (IFP, $\mathrm{cm}$ ), insertion of the last pod (ILP, cm), plant height $(\mathrm{PH}, \mathrm{cm})$, length of the second internode (L2I, cm), length of the third internode (L3I, cm), length of the fourth internode (L4I, cm), length of the fifth internode (L5I, $\mathrm{cm}$ ), epicotyl diameter (ED, $\mathrm{cm})$, and grain yield (YLD, $\mathrm{kg} / \mathrm{ha}$ ) obtained for the four superior common bean genotypes selected, considering the mean values obtained for the four experiments.

\begin{tabular}{|c|c|c|c|c|c|c|c|c|c|}
\hline \multirow[b]{2}{*}{ Trait } & \multirow[b]{2}{*}{$\mathbf{X}_{\mathbf{0}}$} & \multirow[b]{2}{*}{$\mathbf{X}_{\mathbf{S}}$} & \multirow[b]{2}{*}{$\mathbf{h}^{2} \%$} & \multirow[b]{2}{*}{ GG } & \multirow[b]{2}{*}{ GG\% } & \multicolumn{4}{|c|}{ Selected genotypes } \\
\hline & & & & & & $\begin{array}{l}\text { BRS } \\
\text { Valente }\end{array}$ & $\begin{array}{l}\text { LP 11- } \\
117\end{array}$ & $\begin{array}{c}\text { Guapo } \\
\text { Brilhante }\end{array}$ & $\begin{array}{c}\text { SM } \\
0312\end{array}$ \\
\hline LOD & 5.24 & 4.73 & 64.83 & -0.33 & -6.32 & 4.58 & 5.17 & 4.42 & 4.75 \\
\hline GAS & 5.61 & 5.17 & 63.20 & -0.28 & -5.02 & 5.33 & 5.25 & 4.67 & 5.42 \\
\hline IFP & 15.65 & 14.29 & 87.46 & -1.19 & -7.60 & 14.84 & 14.02 & 14.14 & 14.16 \\
\hline ILP & 42.57 & 37.71 & 87.72 & -4.27 & -10.02 & 41.89 & 37.29 & 34.64 & 37.02 \\
\hline $\mathrm{PH}$ & 56.88 & 49.11 & 93.20 & -7.24 & -12.73 & 53.46 & 48.08 & 45.92 & 48.99 \\
\hline L2I & 4.57 & 4.85 & 70.75 & 0.20 & 4.30 & 4.88 & 4.78 & 4.87 & 4.89 \\
\hline L3I & 6.20 & 6.45 & 69.20 & 0.17 & 2.75 & 6.43 & 6.30 & 6.40 & 6.66 \\
\hline L4I & 8.27 & 8.31 & 70.62 & 0.02 & 0.31 & 8.13 & 8.18 & 8.16 & 8.77 \\
\hline L5I & 10.82 & 10.65 & 80.61 & -0.14 & -1.30 & 10.46 & 10.25 & 10.57 & 11.32 \\
\hline $\mathrm{ED}$ & 5.64 & 5.54 & 85.45 & -0.09 & -1.62 & 5.78 & 5.31 & 5.61 & 5.45 \\
\hline YLD & 1389.42 & 1605.80 & 85.79 & 185.64 & 13.36 & 1600.68 & 1748.68 & 1370.44 & 1703.40 \\
\hline Gain & & & & 172.49 & -23.89 & & & & \\
\hline
\end{tabular}

Genetic gain estimates favorable to the selection of common bean lines with upright plant architecture were obtained for lodging $(-6.32 \%)$, general adaptation score $(-5.02 \%)$, insertion of the last pod $(-10.02 \%)$, plant height $(-12.73 \%)$, length of the second internode $(4.30 \%)$, length of the third internode $(2.75 \%)$, and length of the fifth internode $(-1.30 \%)$. 
However, genetic gain estimates not favorable signal to the objectives of this study were verified for insertion of the first pod, length of the fourth internode, and epicotyl diameter. The superior genetic gain estimate, positive and favorable to the selection, was observed for grain yield (13.36\%), an evidence of the superiority of the genotypes selected for this trait. However, previous studies showed that was possible to obtain genetic gain estimates favorable to the selection of common bean lines with upright plant architecture, evaluated visually by the architecture and lodging scores (negative gains), and with high grain yield (positive gain) in the carioca (de Faria et al., 2013) and black common bean genotypes (de Faria et al., 2014), using regression analysis. Bertoldo et al. (2010), in turn, verified that some plant architecture and grain yield component traits showed genetic gain estimates with positive or negative signal not favorable to the selection of superior common bean lines by the use of classic and desired gains indices. These differences can be justified by the germplasm genetic diversity, by the number of environments evaluated, and by the method of obtaining genetic gain estimates.

The rank sum index enabled the selection of four superior common bean genotypes for upright plant architecture traits and grain yield: BRS Valente, LP 11-117, Guapo Brilhante, and SM 0312. The cultivars BRS Valente and Guapo Brilhante were included as a control of black beans due to their upright plant architecture. Guapo Brilhante also was stable for grain yield in southern Brazil (Ribeiro et al., 2016).

The lines LP 11-117 and SM 0312 of black and carioca beans, respectively, stood out compared to the control cultivars in grain yield, but these lines showed similar lodging scores to those found for the control cultivars. The lines LP 11-117 and SM 0312 have a general adaptation score close to 5.0, which characterizes upright plant architecture with numerous branches and a tendency to prostrate, according to Ribeiro et al. (2010); these lines showed insertion of the first pod $\geq 12 \mathrm{~cm}$, which represents upright plant architecture in common bean plants (Melo, 2009). In addition, the lines LP 11-117 and SM 0312 exhibited insertion of the last pod and plant height within the range of variation observed for the control cultivars, $34.64-41.89 \mathrm{~cm}$ and $45.92-53.46 \mathrm{~cm}$, respectively. The selection of common bean lines with insertion of the last pod and plant height similar to the cultivars BRS Valente and Guapo Brilhante is very important for growing in the rainy and dry seasons in southern Brazil. In the rainy season, mean air temperature are higher, rainfall is more frequent, and there is a greater thermal sum. These factors contribute to a greater vegetative growth of the bean plants, even causing lines that were upright which under other conditions become prostrate, as observed by Teixeira et al. (1999). In the dry season, the cultivation of beans is performed in low mean air temperature and lower thermal sum, resulting in less vegetative growth. However, rainfall is more intense near harvest, causing more susceptibility to lodging. Then, the selection of common bean inbred lines in environmental conditions unfavorable for plant architecture is very important for the breeding program. Common bean cultivars that remain upright under adverse conditions would also remain upright under favorable conditions (Teixeira et al.,1999).

The values of the lengths of the second, third, fourth, and fifth internodes, and the epicotyl diameter obtained for the lines LP 11-117 and SM 0312 were similar to those observed for the cultivars BRS Valente and Guapo Brilhante, validating that the common bean lines selected present upright plant architecture. SM 0312 has indeterminate growth habit with long guides, type III (Table 1), typical of prostrate plant architecture. However, SM 0312 presents shorter lengths of the fourth and fifth internodes and this contributes to 
more resistance to lodging, showing that it is possible to develop carioca common bean cultivars with upright plant architecture.

In our study, superior common bean genotypes were selected based on mean data obtained in four environments. As upright plant architecture traits and grain yield vary according to the common bean genotype, growing environment, and $\mathrm{G} \times \mathrm{E}$ interaction (Zilio et al., 2013; Bertoldo et al., 2014; Carneiro et al., 2017; Ribeiro et al., 2018a,b), the evaluation based on a greater number of environments allow more accuracy in the selection of superior lines by the breeding programs. The genotypes selected in the present study showed upright plant architecture and this was characterized by: lodging (up to 5 score), general adaptation score (up to 5 score), insertion of the first pod (14 to $15 \mathrm{~cm}$ ), insertion of the last pod ( 34 to $42 \mathrm{~cm}$ ), plant height $(45$ to $54 \mathrm{~cm})$, mean length of the second internode $(4.86 \mathrm{~cm})$, mean length of the third internode $(6.45 \mathrm{~cm})$, mean length of the fourth internode $(8.31 \mathrm{~cm})$, mean length of the fifth internode $(10.65 \mathrm{~cm})$, and mean epicotyl diameter $(5.54$ $\mathrm{cm})$. These genotypes also presented high grain yield $(\geq 1370 \mathrm{~kg} / \mathrm{ha})$. This is the common bean ideotype that has upright plant architecture and high grain yield in cultivation at low latitude in southern Brazil. This common bean ideotype model differs from those proposed by Adams (1967) and Acquaah et al. (1991) for cultivation in the United States. It is also different from the common bean ideotype idealized by Bertoldo et al. (2014) for cultivation in high altitude regions in Brazil.

The common bean ideotype model may vary according to the altitude, growing season, and the technological level used for growing common bean. For this reason, it is important to assess the common bean ideotype model for the cultivation conditions. In our investigation, the lines LP 11-117 and SM 0312 and the cultivars BRS Valente and Guapo Brilhante showed a common bean ideotype suitable for cultivation at low altitude in southern Brazil. The lines LP 11-117 and SM 0312 present upright plant architecture and stood out compared to the control cultivars in grain yield; thus, these lines have great potential to be launched as new common bean cultivars for the southern region in Brazil. However, SM 0312 may have restriction in the market due to a grain color that is beige with black streaks. Only, carioca bean cultivars with cream-colored grains with light brown stripes, light background, white halo, and a mass of 100 grains of 22 to $24 \mathrm{~g}$ has a grain pattern that meets the consumers' demand (Ramalho et al., 1998).

\section{ACKNOWLEDGMENTS}

To the National Council for Scientific and Technological Development (CNPq) for financial support and scholarships.

\section{CONFLICTS OF INTEREST}

The authors declare no conflict of interest.

\section{REFERENCES}

\footnotetext{
Acquaah G, Adams MW and Kelly JD (1991). Identification of effective indicators of erect plant architecture in dry beans. Crop Sci. 31: 261-264.

Adams MW (1967). Basis of yield component compensation in crop plants with special reference to the field bean, Phaseolus vulgaris L. Crop Sci. 7: 505-510.
} 
Bertoldo JG, Barili LD, do Vale NM, Coimbra JLM, et al. (2010). Genetic gain in agronomic traits of common bean in the region of Planalto Catarinense. Euphytica. 171: 381-388.

Bertoldo JG, Coimbra JLM, Guidolin AF, de Andrade LRB, et al. (2014). Agronomic potential of genebank landrace elite accessions for common bean genetic breeding. Sci. Agr. 71: 120-125.

Brasil - Ministério da Agricultura e do Abastecimento (2006). Requisitos mínimos para determinação do valor de cultivo e uso de feijão (Phaseolus vulgaris), para a inscrição no registro nacional de cultivares - RNC. Anexo I. Available at [http://www.agricultura.gov.br]. Accessed 05 March 2019.

Carneiro VQ, Silva GN, Cruz CD, Carneiro PCS, et al. (2017). Artificial neural networks as auxiliary tools for the improvement of bean plant architecture. Genet. Mol. Res. 16: 1-12.

Chávez-Mendoza C and Sánchez E (2017). Bioactive compounds from Mexican varieties of common bean (Phaseolus vulgaris): implications for health. Molecules. 22: 1360.

Ciat - International Center for Tropical Agriculture (1987). Standard system for the evaluation of bean germplasm. 1st ed. International Center for Tropical Agriculture, Cali.

Conab - Companhia Nacional de Abastecimento (2019). Série histórica das safras. Feijão total $\left(1^{\circ}, 2^{\circ}\right.$ e $3^{\circ}$ safras $)$. Companhia Nacional de Abastecimento, Brasília. Available at [https://www.conab.gov.br/info-agro/safras/seriehistorica-das-safras?start=20]. Accessed 11 June 2019.

Cruz CD (2016). Software - extended and integrated with the R, Matlab and Selegen. Acta Sci. Agron. 38: 547-552.

Ctsbf - Comissão Técnica Sul Brasileira de Feijão (2012). Informações técnicas para o cultivo de feijão na Região Sul brasileira 2012. Empresa de Pesquisa Agropecuária e Extensão Rural, Florianópolis.

da Cunha WG, Ramalho MAP and Abreu AFB (2005). Selection aiming at upright growth habit common bean with carioca type grains. Crop Breed. Appl. Biotechnol. 5: 379-386.

de Faria LC, Melo PGS, Pereira HS, Del Peloso MJ, et al. (2013). Genetic progress during 22 years of improvement of carioca-type common bean in Brazil. Field Crops Res. 142: 68-74.

de Faria LC, Melo PGS, Pereira HS, Wendland A, et al. (2014). Genetic progress during 22 years of black bean improvement. Euphytica. 199: 261-272.

de Lima MS, Carneiro JES, Carneiro PCS, Pereira CS, et al. (2012). Characterization of genetic variability among common bean genotypes by morphological descriptors. Crop Breed. Appl. Biotechnol. 12: 76-84.

Jost E, Ribeiro ND, Maziero SM, Possobom MTDF, et al. (2013). Comparison among direct, indirect and index selections on agronomic traits and nutritional quality traits in common bean. J. Sci. Food Agric. 93: 1097-1104.

Maziero SM, Ribeiro ND, Storck L (2015). Simultaneous selection in beans for architecture, grain yield and minerals concentration. Euphytica. 205: 369-380.

Melo LC (2009). Procedimentos para condução de experimentos de valor de cultivo e uso em feijoeiro comum. Embrapa Arroz e Feijão, Santo Antônio de Goiás.

Mendes FF, Ramalho MAP and Abreu AFB (2011). Eficiência do sistema de nove covas na seleção de progênies de feijoeiro tipo carioca para arquitetura ereta. Pesq. Agropec. Bras. 46: 1029-1034

Moura MM, Carneiro PCS, Carneiro JES and Cruz CD (2013). Potencial de caracteres na avaliação da arquitetura de plantas de feijão. Pesq. Agropec. Bras. 48: 417-425.

Mulamba NN and Mock JJ (1978). Improvement of yield potential of the Eto Blanco maize (Zea mays L.) population by breeding for plant traits. Egypt J. Genet. Cytol. 7: 40-51.

Pereira HS, Almeida VM, Melo LC, Wendland A, et al. (2012). Influência do ambiente em cultivares de feijoeirocomum em cerrado com baixa altitude. Bragantia. 71: 165-172.

Pires LPM, Ramalho MAP, Abreu AFB and Ferreira MC (2014). Recurrent mass selection for upright plant architecture in common bean. Sci. Agr. 71: 240-243.

Ramalho MAP, Pirola LH and Abreu AFB (1998). Alternativas na seleção de plantas de feijoeiro com porte ereto e grão tipo carioca. Pesq. Agropec. Bras. 33: 1989-1994.

Resende MDV and Duarte JB (2007). Precisão e controle de qualidade em experimentos de avaliação de cultivares. Pesq. Agropec. Trop. 37: 182-194.

Ribeiro ND, Cargnelutti Filho A, Poersch NL and Rosa DP (2010). Critério de seleção indireta para a produtividade de grãos em feijão. Cienc. Rural. 40: 986-989.

Ribeiro ND, Casagrande CR, Mezzomo HC, Possobom MTDF, et al. (2016). Simultaneous selection in beans for stability and high agronomic performance. Genet. Mol. Res. 15: 1-14.

Ribeiro ND, dos Santos GG, Maziero SM and Steckling SM (2018a). Phenological, plant architecture, and grain yield traits on common bean lines selection. Rev. Caatinga. 31: 657-666.

Ribeiro ND, Kläsener GR, Mezzomo HC, Possobom MTDF, et al. (2018b). Combined selection in beans for cycle, plant architecture and grain yield. Biosc. J. 34: 108-119.

Schmit R, de Melo RC, Pereira TCV, Beck M, et al. (2016). Application of multivariate techniques in the evaluation of pure lines of beans. Cienc. Rural. 46: 1535-1541.

Silva CA, Abreu AFB and Ramalho MAP (2009). Associação entre arquitetura de planta e produtividade de grãos em progênies de feijoeiro de porte ereto e prostrado. Pesq. Agropec. Bras. 44: 1647-1652.

Silva VMP, Carneiro PCS, Menezes Júnior JAN, Carneiro VQ, et al. (2013). Genetic potential of common bean parents for plant architecture improvement. Sci Agr. 70: 167-175. 
Soltani A, Bello M, Mndolwa E, Schroder S, et al. (2016). Targeted analysis of dry bean growth habit: interrelations among architectural, phenological, and yield components. Crop Sci. 56: 3005-3015.

Teixeira FF, Ramalho MAP, Abreu AFB (1999). Genetic control of plant architecture in the common bean (Phaseolus vulgaris L.). Genet. Mol. Biol. 22: 577-582.

Zilio M, Souza CA, Coelho CMM, Miquelluti DJ, et al. (2013). Cycle, canopy architecture and yield of common bean genotypes (Phaseolus vulgaris) in Santa Catarina State. Acta Sci. Agron. 35: 21-30. 